DOI: 10.34015/2523-4552.2021.3.06

УДК 343.9.02

\author{
Околіт О. В., \\ аспірант наукової лабораторії \\ з проблем протидії злочинності \\ НнІ № 1 Національної академії \\ внутрішніх справ \\ ORCID: 0000-0001-6498-6209
}

\title{
ЗЛОЧИННА СПІЛЬНОТА ЯК ФОРМА СПІВУЧАСТІ
}

У статті аналізуються актуальні проблеми, пов'язані із введенням в кримінально-правовий обіг поняття «злочинна спільнота». Сформульовано авторську позицію щодо кримінально-правової природи цього організованого злочинного об'єднання, розкрито його кримінально-правові ознаки, а також здійснено оцінку обгрунтованості такого кроку законодавця шляхом виокремлення переваг та недоліків цієї законодавчої новації. Аргументовано, що злочинна спільнота, незважаючи на те, що вона не визначена у ст. 28 КК України, є самостійною формою співучасті. Встановлено, що визначення злочинної спільноти потребує уточнення шляхом доповнення його іншими злочинними об'єднаннями, які можуть утворювати досліджувану форму співучасті, принаймні організованою групою.

Ключові слова: організована злочинність; організована група; злочинна організація, злочинна спільнота; співучасть; злочинна діяльність; криміналізація; злочинний вплив; «злодій в законі».

В статье анализируются актуальные проблемы, связанные с введением в уголовно-правовой оборот понятия «преступное сообщество». Сформулирована авторская позиция относительно уголовно-правовой природы этого организованного преступного объединения, раскрыты его уголовноправовые признаки, а также проведена оценка обоснованности такого шага законодателя путем выделения преимуществ и недостатков этого законодательного новшества. Аргументировано, что преступное сообщество, несмотря на то, что оно не определено в ст. 28 УК Украины, является самостоятельной формой соучастия. Установлено, что определение преступного сообщества требует уточнения путем дополнения его другими преступными объединениями, которые могут образовывать исследуемую форму соучастия, по крайней мере, организованной группой.

Ключевые слова: организованная преступность; организованная группа; преступная организация; преступное сообщество; соучастие; преступная деятельность; криминализация; преступное влияние; «вор в законе».

Постановка проблеми. В умовах загострення суспільнополітичної ситуації в Україні в результаті гібридної війни на Сході, анексії Криму й окупації окремих територій Донецької та Луганської областей, а також помилок допущених під час реформування системи

(c) Околіт О. В., 2021 
органів кримінальної юстиції, серйозну стурбованість викликає діяльність учасників організованих злочинних об'єднань, які під керівництвом кримінальних авторитетів здатні ще більше погіршити ситуацію в державі.

У зв'язку з цим з метою підвищення кримінально-правової охорони громадської безпеки від діяльності кримінальних авторитетів та інших учасників організованих злочинних об'єднань 4 червня $2020 \mathrm{p}$. прийнято Закон України «Про внесення змін до деяких законодавчих актів України щодо відповідальності за злочини, вчинені злочинною спільнотою» [1]. Цим так званим законом про «ворів в законі», який набрав чинності 27 червня 2020 р., внесено суттєві зміни в підстави кримінальної відповідальності учасників організованої злочинної діяльності та звільнення від неї, передбачені ст. 255 Кримінального кодексу (далі - КК) України - «Створення, керівництво злочинною спільнотою або злочинною організацією, а також участь у ній».

Аналіз останніх досліджень i публікацій. Проблемні питання кримінальної відповідальності за створення злочинної спільноти та керівництво нею досліджено в працях О. О. Бахуринської, А. А. Вознюка, О.О. Дудорова, О. О. Кваші, $\begin{array}{ll}\text { С. Г. Киренка, } & \text { В. В. Малюка, }\end{array}$ М. Ф. Фоменко, П. Л. Фріса, І. П. Фріса, С. С. Чернявського та інших науковців. Разом із тим чимало питань, пов'язаних із кваліфікацією дій учасників злочинної спільноти залишаються недостатньо дослідженими.

Постановка завдання. 3 огляду на зазначене виникла необхідність в опрацюванні проблемних питань, пов'язаних із кваліфікацією дій учасників злочинної спільноти та пошуку шляхів їх розв'язання.

Виклад основного матеріалу. Введення до КК України такого терміну як «злочинна спільнота» обумовлює необхідність встановлення кримінально-правової природи цього організованого злочинного об'єднання, розкриття його кримінально-правових ознак, визначення критеріїв відмежування злочинної спільноти від злочинної організації, а також здійснення оцінки обгрунтованості такого кроку законодавця.

Аналіз положень ч. 4 ст. 255 КК України свідчить про те, що під злочинною спільнотою слід розуміти об'єднання двох чи більше злочинних організацій. Аналіз цього положення та його місця в системі норм та інститутів кримінального права дає підстави виділити окремі дискусійні моменти.

Чи є злочинна спільнота самостійною бормою співучасті у злочині?

В контексті цього слід звернути увагу на той факт, що у $\mathrm{cm} .28$ КК України відсутнє визначення злочину, учиненого злочинного спільнотою. Хоча ще на етапі підготовки законопроєкту фахівці Головного юридичного управління акцентували на тому, що проектом не вносяться зміни до статті 28 цього Кодексу, які дозволяли б сформувати уявлення про спільність діяльності учасників злочинної спільноти (наприклад, спрямованість їх умислу для вчинення певного злочину; єдність наміру всіх співучасників вчинити одне й те саме кримінальне правопорушення тощо). Такий законодавчий підхід не дає змоги належним чином 
провести відмежування таких суміжних форм співучасті, як «злочинна організація» та «злочинна спільнота». Відтак, і процес доказування створення злочинної спільноти буде зведено до доведення факту об'єднання двох чи більше злочинних організацій, який можна буде поставити під сумнів [2].

На зазначену прогалину неодноразово звертали увагу вчені. O.I. Міневич визнала правовою помилкою порушення системних зв'язків між нормами Загальної та Особливої частини КК України. За ч. 4 ст. 255 цього Кодексу, злочинна спільнота - це об'єднання двох чи більше злочинних організацій. У ч. 4 ст. 28 КК України закріплені обов'язкові ознаки злочинної організації, які відображають їі специфіку. Однак відповідних ознак злочинної спільноти законодавець не визначив і необхідних доповнень до ст. 28 не зробив, унаслідок чого у Загальній частині КК України будьяка вказівка на злочинну спільноту відсутня [3, с. 123]. П. Фріс та I. Фріс характеризуючи цю ситуацію влучно підсумовують, що ми маємо справу із неврегульованою чинним законом формою злочинного об'єднання злочинною спільнотою, що утворює законодавчу прогалину, яка за елементарною логікою повинна бути заповненою [4]. Має рацію 0.0. Кваша, що закріплення в Особливій частині нової форми співучасті - злочинної спільноти, що вимагає паралельного внесення цієї новели до ст. 28 Загальної частини КК, яка закріплює форми співучасті у кримінальному правопорушенні [5, c. 396-397].

Так як законодавець не вніс до ст. 28 КК України, яка визначає фор- ми співучасті, зміни стосовно злочинної спільноти, виникає запитання чи $є$ злочинна спільнота самостійною формою співучасті?

Для відповіді на це питання слід встановити, що таке форма співучасті у злочині взагалі. Формою співучасті пропонується вважати спосіб організації умисної спільної участі декількох суб'єктів злочину у вчиненні умисного злочину. Ї̈̈ визначають характерні для злочинного об'єднання кримінально-правові ознаки [6, с. 54].

3 огляду на зазначене злочинна спільнота $\epsilon$ формою співучасті у випадку, якщо злочинні організації, що її утворюють, об'єднуються з метою вчинення злочину. Об'єднання злочинної організації 3 будь-якою іншою метою, зокрема не протиправною - позитивною, співучасті у формі злочинної спільноти не утворює.

Отже, можна стверджувати, що злочинна спільнота, незважаючи на те, що вона не визначена у ст. 28 КК України, $€$ самостійною формою співучасті. На підтвердження висловленої тези варто взяти до уваги той факт, що форми співучасті закріплені не лише у ст. 28 КК України, але й у інших статтях цього кодексу. А. А. Вознюк робить слушний висновок, що усі види злочинних об'єднань, про які йде мова у ст. 28 КК України, так й інших статтях КК України, зокрема ст. 143, 181, 257, 258-3, 260, 392 КК України, слід визнавати самостійними формами співучасті [7, с. 52]. На думку П. Фріса та I. Фріса як це видно із самої назви закону він впроваджує в кримінально-правове поле нову для нашого законодавства форму співучасті у злочині «злочинну спільноту» [4]. 
0. О. Кваша також справедливо наголошує, що відбулось закріплення в Особливій частині нової форми співучасті - злочинна спільнота, без необхідного дзеркального внесення змін до ст. 28 КК України [8, с. 45].

Кримінально-правові ознаки злочинної спільноти

Злочинна спільнота характеризується двома ознаками: 1) вона складається 3 двох чи більше злочинних організацій; 2) ці злочинні організації об'єдналися в нове організоване злочинне об'єднання. Мають рацію вчені в тому, що для доведення наявності злочинної спільноти необхідно встановити кримінально-правові ознаки двох чи більше злочинних організацій (кожної окремо взятої), а потім додаткову ознаку - факт їx (організацій) об'єднання [9, с. 19].

Виходячи 3 того, що злочинна спільнота складається з двох і більше злочинних організацій це одне 3 найнебезпечніших та найчисельніших за мінімальним складом ${ }^{1}$ організоване злочинне об'єднання (складається як мінімум 3 десяти суб'єктів кримінальних правопорушень). Злочинна спільнота має складну ієрархічну структуру, оскільки об'єднує ієрархії двох і більше злочинних організацій в межах однієї. Така структура повинна включати одного чи декількох організаторів, які здійснюють за- гальне керівництво злочинною спільнотою, а також організаторів, які здійснюють керівництво структурними частинами злочинної спільноти (такими частинами очевидно стають зокрема i злочинні організації після їх об’єднання у злочинну спільноту). Ймовірно один організатор може керувати як злочинною організацією, яка увійшла у злочинну спільноту, так і усією злочинною спільнотою, за умови підпорядкування йому інших учасників злочинної спільноти. Керівником злочинної спільноти, як свідчить практика, може бути «вор в законі» або кримінальний авторитет нижчого рівня. Асоціація злочинної спільноти з «вором в законі» простежувалася в розробників законопроєкту 3 самого початку2.

У ч. 4 ст. 255 КК України задекларовано, що злочинна спільнота складається виключно зі злочинних організацій. 3 огляду на зазначене можна зробити два висновки: 1) злочинна спільнота виникає в результаті об'єднання принаймні двох злочинних організацій, а не будьяких інших злочинних об'єднань, наприклад, злочинної організації та організованої групи; 2) водночас це не означає, що до злочинної спільноти не можуть входити інші злочинні об'єднання, наприклад, організовані групи (тобто злочинною спільнотою може бути визнано об'єднання двох

${ }^{1}$ Кількісний склад злочинного об'єднання може бути мінімальним та максимальним. Мінімальний кількісний склад - це обов'язкова кримінально-правова ознака будь-якого злочинного об'єднання, оскільки вона визначає, ознаки якого злочинного об'єднання вбачаються в злочині, вчиненому [10, с. 45].

2 У проєкті Закону України «Про внесення змін до Кримінального кодексу України щодо відповідальності за злочини, вчинені злочинною спільнотою» від 02.12.2019 № 2513 пропонувалося доповнити ст. 28 КК України ч. 5 такого змісту: «Злочин визнається вчиненим злочинною спільнотою, якщо він скоєний стійким ієрархічним об'єднанням декількох осіб (п'ять і більше), учасником, організатором, керівником та/або координатором якої є «злодій у законі»» [11]. 
злочинних організацій і однієї чи декількох організованих груп).

Позиція законодавця про те, що злочинною спільнотою $\epsilon$ лише об'єднання двох чи більше злочинних організацій є дискусійною. Адже виникає цілком закономірне питання: Чому законодавець обмежився лише злочинними організаціями та не передбачив можливість виникнення злочинної спільноти на базі організованих груп, груп осіб за попередньою змовою чи індивідуальних суб'єктів? Недоліком відповідного нормативного формулювання злочинної спільноти (ч. 4 ст. 255 КК) А. А. Вознюк та О. О. Дудоров слушно називають неврахування тієї обставини, що до складу злочинної спільноти можуть входити й організовані групи [12, с. 25].

П. Фріса та І. Фріса в контексті цього слушно відмітили, що злочинну спільноту не можна визначати, як об'єднання виключно злочинних організацій. До злочинної спільноти окрім злочинних організацій можуть входити і організовані злочинні групи. Не можна визначати структуру виключно на основі об'єднання однорідних таких структур. Життя набагато складніше ніж голе теоретизування, і практика це підтверджує. Якщо проаналізувати діяльність відомих в 90-ті роки XX століття злочинних об'єднань (спільнот) таких, як російські «Солнцевське», «Долгопрудненське», кримські «Башмаки» та ін., то можна переконатися в справедливості такого твердження, адже до їх складу входили як злочинні організації, так i організовані злочинні групи. Те саме спостерігається при аналізі організованої злочинності в США, Італії, країнах Східної Азії тощо. 3 огляду на це під час підготовки до другого читання законопроєкту, ухваленого як Закон від 4 червня 2020 р., I. Фрісом висував пропозицію доповнити ст. 28 КК частиною 5 відповідного змісту («Злочин визнається вчиненим злочинною спільнотою, якщо він скоєний стійким ієрархічним об'єднанням декількох організованих злочинних груп або злочинних організацій»), однак вона не була врахована профільним комітетом [4].

М. Ф. Фоменко також вважає сумнівною позицію законодавця, який основою створення злочинної спільноти визнав тільки злочинні організації. Адже в міжнародноправових актах, які ратифіковані Україною (наприклад, Конвенції ООН проти транснаціональної організованої злочинності) говориться саме про організовану злочинну групу та структурно оформлену групу, які за змістовними характеристиками свідчать про високий ступінь суспільної небезпечності ${ }^{1}$. Для прикла-

1 Водночас існують дослідження, які доводять, що криміналізація в одних країнах дій учасників організованої групи, а в інших - злочинної організації частково зумовлена врахуванням законодавцями цих країн рекомендацій різних міжнародних правових актів: в одних випадках - Конвенції ООН проти транснаціональної організованої злочинності від 15 листопада 2000 р., а в інших - Рамкового рішення Ради ЄС про боротьбу з організованою злочинністю від 24 жовтня 2008 р. [13, с. 5].

Зіставлення кримінально-правових ознак організованої групи, про яку йдеться в Конвенції ООН проти транснаціональної організованої злочинності від 15 листопада 2000 р., та злочинної організації, яка визначена в Рамковому рішенні Ради ЄС про боротьбу з організованою злочинністю від 24 жовтня 2008 р. дає підстави для висновку, що це фактично тотожні за своєю природою злочинні об'єднання. Отже, у цих міжнародних нормативно-правових актах ідеться про одне й те саме злочинне об'єднання [14, с. 239].

(c) Околіт О. В., 2021

89 | С торінка 
ду, кримінальні кодекси РФ, Молдови передбачають створення злочинної спільноти шляхом об'єднання злочинних (організованих) груп або структурованою організованою групою (КК РФ). I це далеко не єдиний приклад такого підходу у розумінні аналізованого явища у законодавствах країн європейського простору. Вбачається, що визначення організованих форм співучасті в національному кримінальному законодавстві (ч. 4, 5 ст. 28 КК України) не відповідає тим підходам, які використовуються міжнародною спільнотою у боротьбі з цими явищами $[15$, c. 270].

Доречно зауважити, що у кримінології злочинну спільноту розуміють як об'єднання організаторів та лідерів злочинного середовища, створюване для координації та упорядкування злочинної діяльності тощо [16, с. 192-193]. Водночас як відомо до організаторів і лідерів злочинного середовища можна віднести осіб, які керують не лише злочинною організацією, але й іншими злочинними об'єднаннями, наприклад, організованою групою.

Таким чином визначення злочинної спільноти потребує уточнення шляхом доповнення його іншими злочинними об'єднаннями, які можуть утворювати досліджувану форму співучасті, принаймні організованою групою.

Цілком очевидно, що до складу злочинної спільноти можуть входити й інші злочинні об'єднання, однак виникає питання як оцінювати дії їх учасників відповідно до положень про форми співучасті, адже з таким входженням у них з'являються додаткові ознаки. Вбачаються принаймні такі варіанти кримінальноправової оцінки: 1) їх статус залишається таким, яким був до об'єднання, i це не впливає на кваліфікацію; 2) вони стають учасниками злочинної спільноти; 3) 3 появою нових кримінальноправових ознак вони можуть перетворитися в більш небезпечну форму співучасті (наприклад, група осіб за попередньою змовою - в організовану групу; організована група - в злочинну організацію). Ймовірно у другому та третьому варіанті мова йде про трансформацію злочинних об'єднань ${ }^{1}$. А. А. Вознюк 3 цього приводу зауважує, що у будь-якому разі злочин, учинений у співучасті, необхідно визнавати вчиненим $\mathrm{y}$ складі того об'єднання, ознаки якого були характерні співучасникам $\mathrm{y}$ момент учинення кожного злочину до й після трансформації $[18$, с. 54]. Однак слід взяти до уваги той факт, що у ст. 255 КК України не встановлено кримінальної відповідальності за участь у злочинній спільноті. Відтак, дії учасників відповідних злочинних об'єднань, які увійшли до злочинної спільноти, крім осіб, які створювали злочинну спільноту чи керували нею, і беруть в ній участь, можна кваліфікувати за наявності відповідних підстав лише як участь у злочинній організації.

Злочинна спільнота $\epsilon$ об'єднанням злочинних організацій.

1 Трансформація злочинних об'єднань - це зміна їх істотних властивостей, унаслідок чого злочинне об'єднання перетворюється з одного виду в інший $[17$, с. $70 ; 18$, с. 53]. 
У тлумачному словнику термін «об'єднання» має такі значення: 1) ціле, що склалося на основі з'єднання, поєднання чого-небудь; 2) організація людей на основі спільності мети, завдань; спілка; 3) назва підприємства, що включає декілька підприємств, організацій, установ [19, с. 802]. Екстраполюючи значення цього терміну на злочинну спільноту можна стверджувати, що ця організація людей відбувається на основі спільності мети чи завдань. Злочинна спільнота це постійне чи тимчасове організоване злочинне об'єднання утворене 3 двох і більше злочинних організацій з певною метою або для виконання певних завдань, пов'язаних 3 кримінально протиправною діяльністю. Метою злочинної спільноти може бути оптимізація, координація кримінально протиправної діяльності, необхідність дотримання правил, звичаїв, традицій злочинного світу, надання взаємодопомоги, формування та наповнення злодійського общака. Мета злочинної спільноти зводиться як правило до вчинення злочинів корисливої чи корисливо-насильницької спрямованості, або встановлення та поширення злочинного впливу.

Варто погодитися з тим, що про об'єднання злочинних організацій може свідчити: 1) встановлення єдиного керівництва злочинної спільноти, яке можуть здійснювати як одна, так i декілька осіб; 2) спільне планування або безпосереднє вчинення злочинів учасниками злочинних організацій, що входять до злочинної спільноти. Для доказування об'єднання злочинних організацій слід встановити його спосіб, причини, обставини $[9$, c. 19].

У теорії кримінального права існують і інші визначення злочинної спільноти, в яких виділяються різні як кримінально-правові, так і кримінологічні ознаки цього організованого злочинного об'єднання.

Наприклад, на думку В. В. Малюка злочинна спільнота це постійно діюче, централізовано сформоване організоване злочинне формування займаючих вищу ступінь злочинної ієрархії осіб суб'єктів підвищеного злочинного впливу, що складається 3 двох i більше злочинних організацій, діючих самостійно в інтересах спільноти, члени яких об'єднані злочинною метою, підпорядковуються встановленим для цієї соціальної групи традиціям та нормам поведінки [20, c. 308]. Злочинна ж спільнота, в кримінологічному сенсі, на переконання О. Бахуринської - це об'єднання організаторів та лідерів злочинного середовища, створюване для координації та упорядкування злочинної діяльності тощо [16, с. 192-193]. Окрім злочинної спільноти вчені виділяють злочинне співтовариство або криміналітет. О. М. Музичук вважає, що криміналітет, тобто злочинне співтовариство (у західній кримінології - «злочинний синдикат») - це особлива форма злочинної організації 3 високорозвинутою внутрішньою структурою, що характеризується певними ознаками: наявністю значної кількості постійних членів професійних злочинців; великою кількістю проведених незаконних операцій; їх здійсненням на значній території, в тому числі на території кількох держав; проведенням кри- 
мінальних операцій на основі складного поділу управлінських функцій і «поділу праці» виконавців; отриманням високої норми прибутку $[21$, с. 32$]$.

Наведене свідчить про різне розуміння терміну «злочинна спільнота», що, очевидно, перешкоджатиме його ефективному застосуванню на практиці. Однак спільним для цих визначень є виокремлення осіб, які займають вищу ступінь ієрархії у злочинному світі. Не випадково поряд з введенням до КК України злочинної спільноти криміналізовано також дії особи, яка здійснює злочинний вплив, зокрема особи, яка перебуває у статусі суб'єкта підвищеного злочинного впливу, у тому числі у статусі «вора в законі». У законодавстві окремих країн пострадянського простору також криміналізовано поведінку відповідних суб'єктів. Наприклад, у КК Вірменії вчинення певних злочинів особою 3 вищим статусом у кримінальній ієрархії визнається кваліфікуючою ознакою складів злочинів, передбачених ст. 222, 223, $223.1,223.2,223.3$ [22]. У ст. 223-1, 223-2, 223-3, 223-4 КК Грузії йдеться про члена злодійського світу та «злодія в законі» [23]. У ст. 210.1 КК Росії криміналізовано зайняття вищого становища в злочинній iєрархії [24].

\section{Доцільність криміналізації злочинної спільноти}

Реакція наукового середовища та практиків на запровадження нової форми співучасті була неоднозначною. Тому варто проаналізувати переваги та недоліки введення злочинної спільноти в сферу кримінально-правового регулювання.
На думку П. Фріса та I. Фріса впровадження в кримінальноправове поле нової для нашого законодавства форми співучасті у злочині - «злочинного співтовариства» само по собі це можна лише вітати, оскільки воно відповідає як кримінально-правовій так і кримінологічній думці [4].

Ймовірно перевагою цієї законодавчої новації $€$ створення терміну, який більш повно та точно характеризує певні організовані злочинні об'єднання, що функціонують у злочинному світі.

Наступна перевага - це встановлення суворішої санкції за створення злочинної спільноти та керівництво нею. У такий спосіб певною мірою забезпечується детальніша диференціація кримінальної відповідальності учасників організованої злочинної діяльності. На думку А. А. Вознюка видається, що єдина користь із такого кроку законодавця - це можливість призначення більш суворого покарання, оскільки санкція ч. 4 ст. 255 КК України містить покарання у вигляді позбавлення волі на строк від десяти до п'ятнадцяти років 3 конфіскацією майна. Аналогічні дії (йдеться про створення та керівництво) щодо злочинної організації караються позбавленням волі на строк від семи до дванадцяти років 3 конфіскацією майна. 3 огляду на практику призначення покарання для учасників злочинних організацій, важливе значення має нижня межа позбавлення волі у зазначених санкціях, оскільки для цих суб'єктів досить часто покарання призначається у мінімальних межах, а в певних випадках - нижче від най- 
нижчої межі ${ }^{1}$. Нижня межа санкції ч. 1 ст. 255 КК України відрізняється від нижньої межі санкції ч. 4 ст. 255 КК України на три роки. Водночас як мінімальні межі санкцій ч. 1 ст. 255 КК України (сім років позбавлення волі) та ч. 4 ст. 255 КК України (десять років позбавлення волі) фактично не дозволяють застосувати звільнення від покарання з випробуванням, якщо, звісно, не буде призначене покарання із застосуванням ч. 1 ст. 69 КК України або ч. 5 ст. 65 КК України.

Водночас висловлюються і вагомі аргументи на користь недоцільності вищезазначеної законодавчої новації.

0. О. Кваша зауважує, що введення до ст. 255 КК України нової форми співучасті (злочинна спільнота) та інші змістовні зміни цієї статті не узгоджуються з іншими нормами та чинною кримінально-правовою термінологією, суперечать системній будові та принципам українського кримінального права та правилам лінгвістики, тому в перспективі лише ускладнять роботу системи кримінальної юстиції [5, с. 399; 8, с. 47].

На думку А. А. Вознюка аналіз кримінально-правових ознак цієї форми співучасті, а також предмету доказування у кримінальних провадженнях щодо створення цього злочинного об'єднання чи керівництва ним, дає підстави стверджувати, що пропозиція щодо введення нової форми співучасті $\epsilon$ не просто необгрунтованою, а, навіть, шкідливою [26, с. 52].

По-перше, органам досудового розслідування необхідно буде довести кримінально-правові ознаки кожної окремо взятої злочинної організації, а потім додаткову ознаку факт об'єднання злочинних організацій. За таких обставин правоохоронці замість того, щоб припинити діяльність першої злочинної організації відразу після завершення ії документування, здійснити якомога швидше розслідування відповідного кримінального провадження (яке на практиці, як правило, навпаки занадто тривале) та передачу його до суду, повинні будуть «притримувати» відповідні матеріали розслідування, до тих пір, доки не буде задокументована друга злочинна організація та факт іiі об'єднання 3 першою. За таких обставин терміни розслідування кримінальних проваджень будуть ще довшими, а сторона захисту матиме ще більше можливостей затягнути процес досудового розслідування. Водночас правоохоронні органи не в повній мірі виконуватимуть функцію запобігання кримінальним правопорушенням (в

1 Дослідження судової практики призначення покарання учасникам злочинних організацій, які були засуджені протягом 2007-2016 рр. ще за старою редакцією ст. 255 КК України, свідчить про те, що призначення покарання для 41,3 \% осіб відбувалося із застосуванням ч. 1 ст. 69 КК України, а 45,6 \% засуджених одержало позбавлення волі в мінімальній межі санкції (строком на 5 років). Тобто 86,9 \% учасникам злочинної організації позбавлення волі призначено в максимально можливій мінімальній межі санкції та нижче такої межі. Отже, лише 13,1 \% засуджених за вчинення злочинів, передбачених ст. 255 КК України, одержали покарання не в максимально можливій його мінімальній межі, закріпленій у санкції цієї статті. У результаті засудження учасників злочинних організацій за сукупністю злочинів у 57,8 \% випадків строк позбавлення волі також не перевищує 5 років, тобто відповідає мінімальним межам санкції [25, с. 747, 907-908]. 
аспекті несвоєчасного, мабуть «запізнілого» реагування на факти кримінально протиправної діяльності). Фактично доказування злочинної спільноти - це «зайве навантаження» для правоохоронців [26, с. 52]. Таке ускладнення недоречне особливо за обставин, коли як слушно зауважують вчені результат роботи правоохоронних органів у сфері боротьби з організованою злочинністю перестав бути адекватним обсягу і рівню витрачених зусиль; правоохоронні органи не встигають своєчасно й ефективно реагувати на зміну якості організованої злочинності і появу нових видів злочинів; органи правопорядку за такої стратегії боротьби зі злочинністю не встигають стримувати ії зростання [27, с. 413].

По-друге, можна прогнозувати, що такі об'єднання, якщо і виявлятимуться, то не більше 1-2 у рік. Водночас, вироків варто очікувати ще менше, тобто, не більше одного на декілька років [28, с. 180].

Тому вчені роблять слушний висновок, що наявних у КК України форм співучасті цілком достатньо для ефективної диференціації кримінальної відповідальності учасників організованих злочинних об'єднань [26, с. 53], а також для забезпечення належної кримінальноправової протидії спільній злочинній діяльності, у тому числі організованій [5, с. 397]. Вони повністю охоплюють усі можливі форми існування злочинних об'єднань, а введення нових - $є$ зайвим навантаженням як на закон про кримінальну відповідальність, так і на роботу органів кримінальної юстиції [26, с. 53].

Висновки. Підбиваючи підсумки проведеного дослідження, варто сформулювати низку висновків.
Злочинна спільнота, незважаючи на те, що вона не визначена у ст. 28 КК України, $є$ самостійною формою співучасті. Злочинна спільнота характеризується двома ознаками: 1) вона складається 3 двох чи більше злочинних організацій; 2) ці злочинні організації об'єдналися в нове організоване злочинне об'єднання.

У ч. 4 ст. 255 КК України задекларовано, що злочинна спільнота складається виключно зі злочинних організацій. 3 огляду на зазначене можна зробити два висновки: 1) злочинна спільнота виникає в результаті об'єднання принаймні двох злочинних організацій, а не будьяких інших злочинних об'єднань, наприклад, злочинної організації та організованої групи; 2) водночас це не означає, що до злочинної спільноти не можуть входити інші злочинні об'єднання, наприклад, організовані групи (тобто злочинною спільнотою може бути визнано об'єднання двох злочинних організацій i однієї чи декількох організованих груп).

Визначення злочинної спільноти потребує уточнення шляхом доповнення його іншими злочинними об'єднаннями, які можуть утворювати досліджувану форму співучасті, принаймні організованою групою.

Злочинна спільнота це постійне чи тимчасове організоване злочинне об'єднання утворене з двох і більше злочинних організацій 3 певною метою або для виконання певних завдань, пов'язаних 3 кримінально протиправною діяльністю. Метою злочинної спільноти може бути оптимізація, координація кримінально протиправної діяльності, необхідність дотримання правил, звичаїв, традицій злочинного світу, 
надання взаємодопомоги, формування та наповнення злодійського общака. Мета злочинної спільноти зводиться як правило до вчинення злочинів корисливої чи корисливонасильницької спрямованості, або встановлення та поширення злочинного впливу.

Перевагами введення злочинної спільноти в сферу кримінальноправового регулювання $є$ створення терміну, який більш повно та точно характеризує певні організовані злочинні об'єднання, що функціонують у злочинному світі, а також можливість призначення більш суворого покарання за створення злочинної спільноти та керівництво нею 3 огляду на суворіші санкції ч. 4 ст. 255 КК України. Таким чином забезпечується детальніша диференціація кримінальної відповідальності учасників організованої злочинної діяльності.

Головним недоліком цієї законодавчої новації є труднощі доказування нової форми співучасті, запізніле реагування на факти кримінально протиправної діяльності організованих злочинних об'єднань та зайве навантаження на правоохоронців.

\section{Список використаних джерел}

1. Про внесення змін до деяких законодавчих актів України щодо відповідальності за злочини, вчинені злочинною спільнотою: Закон України від 4 червня 2020 p. № 671-IX. URL: https://zakon.rada.gov.ua/laws/show/671-20\#n7.

2. Про внесення змін до Кримінального кодексу України щодо відповідальності за злочини, вчинені злочинною спільнотою: зауваження Головного юридичного управління від 16 січня 2020 р. до проєкту Закону України від 2 грудня 2019 р. № 2513. URL: http://w1.c1.rada.gov.ua/pls/zweb2/webproc4_2?pf3516=2513\&skl=10

3. Міневич О.І. Поняття та види правових помилок: загальнотеоретичне дослідження: дис. ... канд юрид. наук: 12.00.01. Одеса, 2021. 237 с.

4. Фріс П., Фріс І. Про боротьбу зі злочинними спільнотами (нотатки на полях закону). Юридичний вісник України. 17-30 лип. 2020 р., № 28-29.

5. Кваша О. О. Вдосконалення законодавства у сфері протидії організованим формам злочинності: ілюзії та реальність. Правова держава. Вип. 32. Київ: Ін-т держави і права ім. B.M. Корецького НАН України, 2021. С. 394-403. DOI: 10.33663/08692491-2021-32-394-403.

6. Вознюк А. А. Визначення поняття «форма співучасті» та її види в теорії кримінального права. Науковий вісник Національної академії прокуратури України. 2015. № 1. С. 46-56.

7. Вознюк А.А. Банди, терористичні об’єднання, не передбачені законом воєнізовані або збройні формування - спеціальні види злочинних об'єднань чи самостійні форми співучасті? Кримінально-правові та кримінологічні засоби протидії злочинам проти громадської безпеки та публічного порядку: матеріали міжнар. наук.практ. конф. до 25-річчя ХНУВС (18 квіт. 2019 р., м. Харків). Харків: ХНУВС, 2019. С. 5153.

8. Кваша 0.0. Злочинна спільнота: критичний погляд на новелу Кримінального кодексу України. Українська модель кримінальної юстиції: блукаючи задзеркаллям. VI (XIX) Львівський форум кримінальної юстиції: матеріали наук.-практ. конф. (17-18 вересня 2020 року). Львів: ЛьвДУВС, 2020. С. 45-48.

9. Кримінальна відповідальність за злочини, вчинені злочинною спільнотою (статті 255, 2551, 255², 2553, 256 Кримінального кодексу України): науково- 
практичний коментар / А. А. Вознюк, О.О.Дудоров, С. С. Чернявський. Киӥв: Норма права, 2021. 130 с.

10. Вознюк А. А. Количественно-качественный состав участников преступлений, совершенных организованными преступными объединениями по УК Украины. Legea şi Viaţa. 2014. № 5/2 (269). C. 44-48.

11. Про внесення змін до Кримінального кодексу України щодо відповідальності за злочини, вчинені злочинною спільнотою: проєкт Закону України № 2513 від 02.12.2019. URL: http://w1.c1.rada.gov.ua/pls/zweb2/webproc4_2?pf3516=2513\&skl=10.

12. Вознюк А., Дудоров О. Кримінальна відповідальність за злочини, вчинені злочинною спільнотою: аналіз законодавчих новел. Новітні кримінально-правові дослідження - 2021: Альманах наукових праць / за ред. проф. Є.Л. Стрельцова, проф. О.В. Козаченка, PhD О.М. Мусиченко. Миколаїв: МІП НУ ОЮА, 2021. С. 21-31.

13. Вознюк А. А. Теоретичні та практичні проблеми кримінальної відповідальності за створення злочинних об'єднань та участь у них як посягання на громадську безпеку: автореф. дис. ... д-ра юрид. наук: 12.00.08. Київ, 2018. 38 с.

14. Vozniuk A., Dudorov O., Tytko A., Movchan R. Implementation of UN and EU recommendations on criminalization of organized crimes. Amazonia Investiga. 2020. Vol. 9, Issue 28 April. P. 234-240. https://doi.org/10.34069/AI/2020.28.04.26

15. Фоменко М. Ф. Створення злочинної спільноти як новела кримінального закону України: проблеми теоретичного та прикладного характеру (ч. 4 ст. 255 КК). Злочинність і протидія їй в умовах сингулярності: тенденції та інновації: матеріали наук.-практ. конф., присвяч. пам'яті члена Правління Кримінологічної асоціації України, проф. Т. А. Денисової (м. Харків, 16 квіт. 2021 р.). Харків: ХНУВС, 2021. С. 269271.

16. Бахуринська О. Поняття «злочинна спільнота»: проблеми правового та кримінологічного визначення. Підприємництво, господарство і право. 2020. № 1. C. 190-195. https://doi.org/10.32849/2663-5313/2020.1.34

17. Вознюк А. А. Трансформація співучасті: поняття та форми. Боротьба з організованою злочинністю і корупцією (теорія і практика). 2014. № 1 (32). С. 68-71.

18. Вознюк А. А. Особливості кваліфікації злочинів під час трансформації співучасті. Науковий вісник Національної академії внутрішніх справ. 2014. № 2 (91). C. 51-59.

19. Великий тлумачний словник сучасної української мови (з дод., допов. та CD) / уклад. і голов. ред. В. Т. Бусел. Київ; Ірпінь: Перун, 2009. 1736 с.

20. Малюк В. В. Основні доктринальні підходи до визначення дефініції «злочинні спільноти». Актуальні проблеми кримінального права: матеріали XI Всеукр. наук.-теорет. конф., присвяч. пам'яті проф. П. П. Михайленка (Київ, 20 листоп. 2020 р.) / [редкол.: В. В. Чернєй, С. Д. Гусарєв, С. С. Чернявський та ін.]. Київ: Нац. акад. внутр. справ, 2020. С. 306-308.

21. Музичук О. М. Криміналітет як форма організації злочинної спільноти. Злочинність і протидія їй в умовах сингулярності: тенденції та інновації: матеріали наук.-практ. конф., присвяч. пам'яті члена Правління Кримінол. асоц. України, проф. Тетяни Андріївни Денисової (м. Харків, 16 квіт. 2021 р.). Харків: ХНУВС, 2021. С. 32-33.

22. Уголовный кодекс Республики Армения от 29 апр. 2003 г. № 3Р-528 по состоянию на 28 октября 2020 г. URL: http://www.parliament.am/ legislation.php?sel=show\&ID=1349\&lang=rus.

23. Уголовный кодекс Грузии от 22 июля 1999 г. № 2287-вс по состоянию на 19 сентября 2020 г. URL: https://www.legislationline.org/ download/id/8847/file/Georgia_Criminal_Code_am2020_ru.pdf.

24. Уголовный кодекс Российской Федерации от 13 июня 1996 г. № 63-Ф3 по состоянию на 22 серп. 2021 p. URL: http://docs.cntd.ru/document/9017477. 
25. Вознюк А. А. Кримінальна відповідальність за створення злочинних об’єднань та участь у них: монографія. Київ: ФОП Маслаков, 2018. 928 с.

26. Вознюк А. А. Актуальні питання кримінальної відповідальності учасників злочинної організації та злочинної спільноти. Актуальні проблеми кримінального права: матеріали XII Всеукр. наук.-теорет. конф., присвяч. пам'яті проф. П. П. Михайленка (Київ, 18 листоп. 2021 р.) / [редкол.: В. В. Чернєй, С. Д. Гусарєв, С. С. Чернявський та ін.]. Київ: Нац. акад. внутр. справ, 2021. С. 51-56.

27. Жаровська Г. П. Транснаціональна організована злочинність в Україні: феномен, детермінація, протидія: монографія. Чернівці: Чернівецький нац. ун-т, 2018. $568 \mathrm{c.}$

28. Вознюк А. Протидія організованій злочинності в Україні: перспективи удосконалення кримінального законодавства. Вісник Пенітенціарної асоціації України. 2020. № 1 (11). C. 176-194. https://doi.org/10.34015/2523-4552.2020.1.18

\section{References}

Minevych, O. I. (2021). Poniattia ta vydy pravovykh pomylok: zahalnoteoretychne doslidzhennia: dys. ... kand yuryd. nauk: 12.00.01. Odesa [in Ukrainian].

Fris, P., Fris, I. (2020). Pro borotbu zi zlochynnymy spilnotamy (notatky na poliakh zakonu). Yurydychnyi visnyk Ukrainy, 28-29 [in Ukrainian].

Kvasha, O. O. (2021). Vdoskonalennia zakonodavstva u sferi protydii orhanizovanym formam zlochynnosti: iliuzii ta realnist. Pravova derzhava, 32, 394-403. DOI: 10.33663/0869-2491-2021-32-394-403 [in Ukrainian].

Vozniuk, A. A. (2015). Vyznachennia poniattia «forma spivuchasti» ta yii vydy v teorii kryminalnoho prava. Naukovyi visnyk Natsionalnoi akademii prokuratury Ukrainy, 1, 46-56 [in Ukrainian].

Vozniuk, A. A. (2019). Bandy, terorystychni ob'iednannia, ne peredbacheni zakonom voienizovani abo zbroini formuvannia - spetsialni vydy zlochynnykh ob'iednan chy samostiini formy spivuchasti? Kryminalno-pravovi ta kryminolohichni zasoby protydii zlochynam proty hromadskoi bezpeky ta publichnoho poriadku: materialy mizhnar. nauk.prakt. konf. do 25-richchia KhNUVS. Kharkiv: KhNUVS, 51-53 [in Ukrainian].

Kvasha, O. O. (2020). Zlochynna spilnota: krytychnyi pohliad na novelu Kryminalnoho kodeksu Ukrainy. Ukrainska model kryminalnoi yustytsii: blukaiuchy zadzerkalliam. VI (XIX) Lvivskyi forum kryminalnoi yustytsii: materialy nauk.-prakt. konf. Lviv: LvDUVS, 45-48 [in Ukrainian].

Vozniuk, A. A., Dudorov, O. O., Cherniavskyi S. S. (2021). Kryminalna vidpovidalnist za zlochyny, vchyneni zlochynnoiu spilnotoiu (statti 255, 2551, 2552, 2553, 256 Kryminalnoho kodeksu Ukrainy): naukovo-praktychnyi komentar. Kyiv: Norma prava [in Ukrainian].

Vozniuk, A. A. (2014). Kolychestvenno-kachestvennыi sostav uchastnykov prestuplenyi, sovershennыkh orhanyzovannыmy prestupnыmy obъedynenyiamy po UK Ukraynu. Legea şi Viaţa, 5/2(269), 44-48 [in Ukrainian].

Vozniuk, A., Dudorov, 0. (2021). Kryminalna vidpovidalnist za zlochyny, vchyneni zlochynnoiu spilnotoiu: analiz zakonodavchykh novel. Novitni kryminalno-pravovi doslidzhennia - 2021: Almanakh naukovykh prats / za red. prof. Ye.L. Streltsova, prof. O.V. Kozachenka, PhD 0.M. Musychenko. Mykolaiv: MIP NU OIuA [in Ukrainian].

Vozniuk, A. A. (2018). Teoretychni ta praktychni problemy kryminalnoi vidpovidalnosti za stvorennia zlochynnykh ob'iednan ta uchast u nykh yak posiahannia na hromadsku bezpeku: avtoref. dys. ... d-ra yuryd. nauk: 12.00 .08 [in Ukrainian].

Vozniuk A., Dudorov O., Tytko A., Movchan R. Implementation of UN and EU recommendations on criminalization of organized crimes. Amazonia Investiga. 2020. Vol. 9, Issue 28 April. P. 234-240. https://doi.org/10.34069/AI/2020.28.04.26

(С) Околіт 0. В., 2021 
Fomenko, M. F. (2021). Stvorennia zlochynnoi spilnoty yak novela kryminalnoho zakonu Ukrainy: problemy teoretychnoho ta prykladnoho kharakteru (ch. 4 st. $255 \mathrm{KK}$ ). Zlochynnist i protydiia yii $v$ umovakh synhuliarnosti: tendentsii ta innovatsii: materialy nauk.prakt. konf., prysviach. pam'iati chlena Pravlinnia Kryminolohichnoi asotsiatsii Ukrainy, prof. T. A. Denysovoi. Kharkiv: KhNUVS, [in Ukrainian].

Bakhurynska, O. (2020). Poniattia «zlochynna spilnota»: problemy pravovoho ta kryminolohichnoho vyznachennia. Pidpryiemnytstvo, hospodarstvo i pravo, 1, 190-195. DOI https://doi.org/10.32849/2663-5313/2020.1.34 [in Ukrainian].

Vozniuk, A. A. (2014). Transformatsiia spivuchasti: poniattia ta formy. Borotba $z$ orhanizovanoiu zlochynnistiu i koruptsiieiu (teoriia i praktyka), 1 (32), 68-71 [in Ukrainian].

Vozniuk, A. A. (2014). Osoblyvosti kvalifikatsii zlochyniv pid chas transformatsii spivuchasti. Naukovyi visnyk Natsionalnoi akademii vnutrishnikh sprav, 2 (91), 51-59 [in Ukrainian].

Maliuk, V. V. (2020). Osnovni doktrynalni pidkhody do vyznachennia definitsii «zlochynni spilnoty». Aktualni problemy kryminalnoho prava: materialy XI Vseukr. nauk.teoret. konf., prysviach. pam'iati prof. P. P. Mykhailenka [in Ukrainian].

Muzychuk, O. M. (2021). Kryminalitet yak forma orhanizatsii zlochynnoi spilnoty. Zlochynnist i protydiia yii $v$ umovakh synhuliarnosti: tendentsii ta innovatsii: materialy nauk.prakt. konf., prysviach. pam'iati chlena Pravlinnia Kryminol. asots. Ukrainy, prof. Tetiany Andriivny Denysovoi. Kharkiv: KhNUVS [in Ukrainian].

Vozniuk, A. A. (2018). Kryminalna vidpovidalnist za stvorennia zlochynnykh ob'iednan ta uchast u nykh: monohrafiia. Kyiv: FOP Maslakov [in Ukrainian].

Vozniuk, A. A. (2021). Aktualni pytannia kryminalnoi vidpovidalnosti uchasnykiv zlochynnoi orhanizatsii ta zlochynnoi spilnoty. Aktualni problemy kryminalnoho prava: materialy XII Vseukr. nauk.-teoret. konf., prysviach. pam'iati prof. P. P. Mykhailenka. Kyiv: Nats. akad. vnutr. Sprav [in Ukrainian].

Zharovska, H. P. (2018). Transnatsionalna orhanizovana zlochynnist v Ukraini: fenomen, determinatsiia, protydiia: monohrafiia. Chernivtsi: Chernivetskyi nats. un-t [in Ukrainian].

Vozniuk, A. (2020). Protydiia orhanizovanii zlochynnosti v Ukraini: perspektyvy udoskonalennia kryminalnoho zakonodavstva. Visnyk Penitentsiarnoi asotsiatsii Ukrainy, 1(11), 176-194. DOI https://doi.org/https://doi.org/10.34015/2523-4552.2020.1.18 [in Ukrainian].

O. Okolit, Postgraduate Student of the Research Laboratory on the Problems of Combating Crime of the Educational and Research Institute No 1 of the National Academy of Internal Affairs, Kyiv, Ukraine.

ORCID: 0000-0001-6498-6209

\section{Criminal community as a form of complicity}

The article analyzes current issues related to the introduction of the concept of "criminal community" in criminal law. The author's position on criminal law nature of this organized criminal association is formulated, its criminal-legal features are revealed, and the validity of such legislative step is assessed by highlighting both advantages and disadvantages of this legislative innovation. It is argued that criminal community, despite the fact that it is not defined in Art. 28 of the Criminal Code of Ukraine, is an separate form of complicity. 
Criminal community is a permanent or temporary organized criminal group formed by two or more criminal organizations for a specific purpose or to perform certain tasks related to criminally unlawful activities.

The definition of a criminal community needs to be clarified by supplementing it with other criminal groups, which may constitute the studied form of complicity, at least by an organized group.

Advantages of introducing a criminal community into the sphere of criminal law regulation are the creation of a term that more fully and accurately describes certain organized criminal associations operating in the criminal world, as well as the possibility of imposing more severe penalties for creating and leading a criminal community, given the stricter sanctions described in part 4 of Art. 255 of the Criminal Code of Ukraine. This provides a more detailed differentiation of criminal liability of participants in organized crime. Instead, the main disadvantage of this legislative innovation is the difficulty of proving a new form of complicity, the late response to the facts of criminally unlawful activities of organized criminal groups and the excessive burden on law enforcement.

Keywords: organized crime; organized group; criminal organization; criminal community; complicity; criminal activity; criminalization; criminal influence; "thief in law». 